\section{Evaluation of low testesterone levels in male dogs with alopecia}

\section{Abstract}

Hypoandrogenism is one of the reasons for alopecia in humans; however it is rarely detected in dogs and cats. To the best of the authors' knowledge, this is the first retrospective report describing only signalment and clinical manifestations of hypoandrogenism in male dogs. A retrospective review of the medical records of 76 male dogs of different breeds and ages with hypoandrogenism from 1999 to 2017 were included to the study. The most common clinical signs were alopecia that started from the tail to the neck and hyperpigmentation. This study identified a variety of cutaneous lesions in male dogs with hypoandrogenism. As there is relatively little published information describing hypoandrogenism in animals, further studies are required to understand the importance of these endocrinopathies.

Keywords: Alopecia, Endocrinopaties, Hypoandrogenism, Male Dog

\section{Alopesili erkek köpeklerde düşük testesteron seviyelerinin incelenmesi}

Özet

Kedi ve köpeklerde nadir olarak saptanmasına rağmen hipoandrojenizm insanlardaki alopesinin nedenlerinden birisidir. Yazarların bilgisine göre, bu çalışma erkek köpeklerde sadece hipoandrojenizmin anamnez ve klinik belirtilerini açılayan ilk retrospektif rapordur. 1999 ile 2017 yılları arasında farklı ırk ve yaş gruplarında 76 erkek köpeğin tıbbi kayıtları retrospektif olarak incelendi ve çalışma kapsamında değerlendirildi. En sık görülen klinik bulgular, kuyruktan boyun bölgesine kadar uzayan alopesi ve hiperpigmentasyondu. Bu çalışma, erkek köpeklerde hipoandrojenizmi olan çeşitli kutanöz lezyonları tanımlamıştır. Hayvanlarda hipoandrojenizmi tanımlayan nispeten az yayınlanmış bilgi olduğu için, bu endokrinopatilerin önemini anlamak için daha fazla çalışmaya ihtiyaç vardır.

Anahtar Kelimeler: Alopesi, Endokrinopatiler, Hipoandrojenizm, Erkek Köpek

\section{Introduction}

One of the important causes of symmetrical alopecia is endocrinopathies in dogs. Although hypotroidism and hyperadrenocorticism are the most frequent causes, sex hormone-related dermatosis is also reported. An imbalance of estrogens, androgens, or progestins is the causes of sex hormone-related dermatoses. Sex hormone imbalances rarely occur in dogs with alopecia. Hyperestrogenism is the most mentioned sex hormone disorder in the veterinary literature. However androgens are the most investigated main hormones of alopecia in humans (Bratha-Robia et al., 2002). Despite androgen-related alopecia which is a common form of hair loss in humans, this hormone imbalance is rare in dogs. Futhermore, to the authors' knowledge and despite the case reports there is no study on alopecic dogs with hypoandrogenism (Crabtree et al., 2010; Schmeitzel, 1990).

Androgens are produced by testicular interstitial cells, ovarian follicular cells, and adrenocortical zona cells (Schmeitzel, 1990; Scott et al., 2001). The pathogenesis of these dermatoses is not well described and the documentation is frequently lacking (Schmeitzel, 1990).
Retrospective Cohort Study

\section{Lora KOENHEMSI Banu DOKUZEYLÜL REMZİ GÖNÜL Erman OR}

Istanbul University, Faculty of Veterinary Medicine, Department of Internal Medicine, Avcilar-Istanbul, Turkey

Corresponding Author

Lora KOENHEMSI

Istanbul University, Faculty of

Veterinary Medicine, Department of Internal Medicine, Avcilar-Istanbul, Turkey. lomekoh@istanbul.edu.tr

Article info Received: 20-07-2018

Accepted: 29-11-2018 https://dx.doi.org/10.31797/vetbio.446368

Commons Attribution 4.0 International License 
Androgens affect epidermal thickness, cutaneous pigmentation, sebaceous gland size, and sebum production (Cerendolo, 2009).

The purpose of this retrospective study is to evaluate the clinical presentation, cutaneous manifestations, and diagnosis of male dogs with hypoandrogenism.

\section{Materials and methods}

A total of 76 neutered male dogs with alopecia from different breeds, and of different ages were included in our study. Physical examinations, routine blood tests (hematological and biochemical), skin scrapings (parasitology and mycology), and hormone tests were performed on all dogs on the presentation day. Dogs with incomplete information and female dogs were ruled out. Dogs with other skin diseases like dermatomycosis, autoimmune disease or demodicosis were excluded from the study.

Clinical signs at presentation were noted. Total cell count, plasma concentrations of glucose, urea, creatinine, Aspartate Aminotransferase (AST), Alanine Aminotransferase (ALT), total protein, and cholesterol were assayed. Endocrine-function tests (testosterone, estradiol, progesterone, triiodothyronine $\left(\mathrm{T}_{3}\right)$, tetraiodothyronine $\left(\mathrm{T}_{4}\right)$, Free $\mathrm{T}_{4}$ (fT4), thyroid stimulating hormone (TSH), and cortisol were done to rule out other endocrinopathies. Antinuclear antibody (ANA test) was also done to rule out autoimmun skin diseases.

\section{Results}

During an eight-year study period, 76 male dogs of different breeds were included in our study. All dogs were neutered. The breeds were; Golden Retriever $(\mathrm{n}=27)$, Siberian Husky ( $\mathrm{n}=6)$, German Shepherd ( $\mathrm{n}=5)$, English Setter $(\mathrm{n}=4)$, Labrador Retriever $(\mathrm{n}=4)$, Rottweiler ( $n=4)$, Chow Chow $(n=2)$, Shar-Pei $(n=1)$, and Terrier $(n=1)$. In addition, there were twenty-two mixed-breed dogs. The median age was nine-years-old

(range one-fourteen years). A six-month-old dog was excluded from the study.

The clinical signs were alopecia, hyperpigmentation, scars, and scales. All dogs had bilateral symmetrical alopecia, only-four of them had post-climbing alopecia. The remaining hairs can be epilated easily. The coat of the dogs was dull and dry. Fifty-one of the dogs had diagnosed with hyperpigmentation (Figure 1a). Twenty-four of them had scars and scales. The distribution of lesions started from the neck area in four dogs and at the tail in other dogs (Figure 1b). Pruritus had diagnosed in only six dogs.

All hematology and blood serum biochemistry levels were within normal limits in these dogs. Skin scrapings for sarcoptic and demodectic mange were negative. Mycologic culture results were also negative.

Progesterone, $\mathrm{T}_{3}, \mathrm{~T}_{4}, \mathrm{fT}_{4}, \mathrm{TSH}$, and cortisol values were normal. Testosterone levels were detected low in all animals and estradiol levels were high in sixteen dogs (Table 1).

Table 1. Mean hormonal values of dogs

Tablo 1. Köpeklerin ortalama hormon değerleri

\begin{tabular}{lll}
\hline & Mean Values & Normal Values \\
\hline T3 $_{3}(\mathbf{n g} / \mathbf{d l})$ & 98 & $50-160$ \\
$\mathbf{T}_{4}(\mathbf{n g} / \mathbf{d l})$ & 1,9 & $1,3-2,9$ \\
$\mathbf{f T}_{4}(\mathbf{n g} / \mathbf{d l})$ & 1,4 & $0,7-2,1$ \\
TSH $(\mathbf{n g} / \mathbf{m l})$ & 0,3 & $0-0,5$ \\
Cortisol $(\mathbf{u g} / \mathbf{d l})$ & 4 & $1,5-6,5$ \\
Progesteron $(\mathbf{n g} / \mathbf{m l})$ & 0,6 & $0-1$ \\
\hline Testesteron $(\mathbf{n g} / \mathbf{d l})$ & 208 & $500-6000$ \\
Eostrodiol $(\mathbf{p g} / \mathbf{m l})$ & 14 & $0-15$ \\
\hline
\end{tabular}




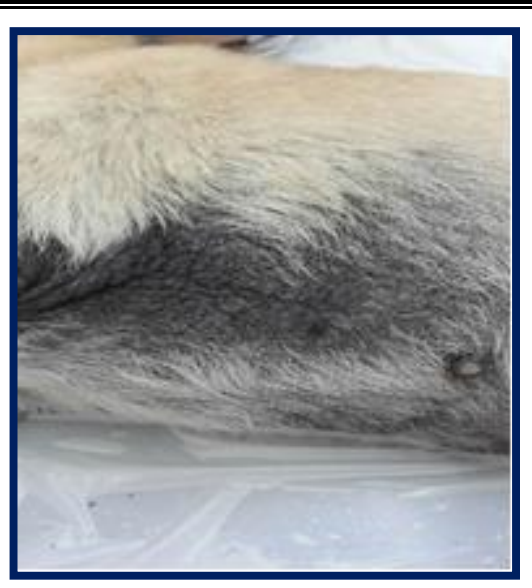

$\mathrm{a}$

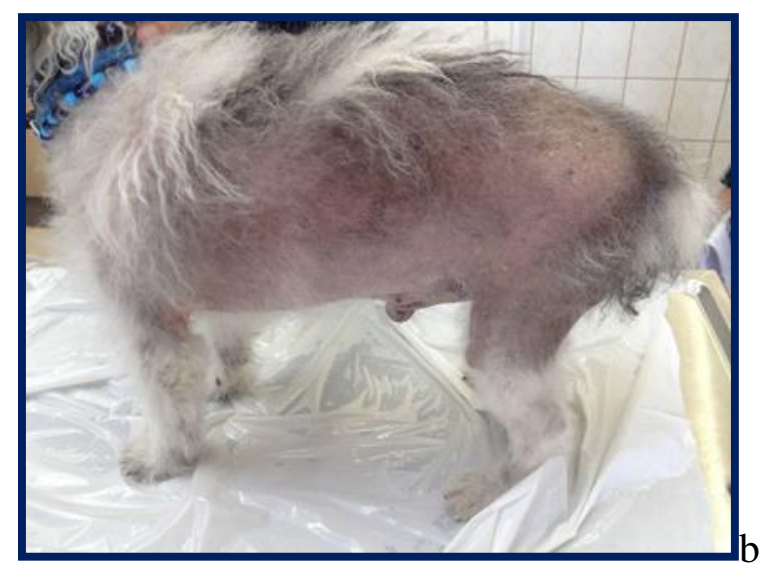

Figure 1: Figure 1a: Hyperpigmentation in a 7 years old dog. Lesions were in the abdominal area. 1b: Alopesia and hiperpigmentation in a 6 years-old Terrier.

Şekil 1a: 7 yaşındaki bir köpekte hiperpigmentasyon. Lezyonlar abdomen bölgesinde bulunmaktadır. 1b: 6 yaşındaki bir Terrier'de alopesi ve hiperpigmentasyon

\section{Discussion}

Canine endocrine dermatoses are characterized by bilateral symmetrical alopecia. Although growth hormone-related and sex hormone-related dermatoses are less common than hypothyroidism and hyperadrenocorticism, they are one of the important causes of endocrine skin disease. Several new syndromes associated with growth and sex hormones have recently been described (Frank et al., 2003; Rosychuck, 2008; Schmeitzel, 1990).

Frank et al. (2003) reported that little work has been done on sex hormones and due to this, testosterone was not evaluated in dogs. Additionally, the sex hormones pathogenesis on the skin is not well elucidated and a few studies related to these hormones have been described in the veterinary literature (Schmeitzel, 1990). This study represents the largest reported collection of canine hypoandrogenism cases to date.

In dogs, sex hormone imbalances are often associated with cutaneous lesions (Cerendolo, 2009; Rosychuck, 2008). The skin and hair follicles are target organs in these abnormalities (Bratha-Robia et al., 2002). Sex hormones help to regulate both skin development and function in animals and humans (Ginel et al., 2009; Rosychuck, 2008). In addition to this, Cerundolo et al. (2009) concluded that hyperestrogenism and hyperandrogenism are the two clinically known disorders that are due to over secretion of testes and ovary tumors. We have identified seventy-six cases of hypoandrenogenism in dogs with alopecia from a hospital population over a seven-year period. Of these, only sixteen of them had hyperestrogenism.

Dogs with hypoandrogenism and hyperestrogenism have a condition known as idiopathic male feminizing syndrome. The exact cause of this syndrome is undetermined. Bilateral symmetrical alopecia, hyperpigmentation, and seborrhea is detected in the affected dogs (Gündüz et al., 2002; Mulligan, 1944; Schmeitzel, 1990). Pruritus and gynecomastia are often present (Gündüz et al., 2002; Schmeitzel, 1990). Also, Gündüz et al. (2002), reported a dog with normal testicles, gynecomastia, and low sperma. All cutaneous symptoms were detected in the sixteen dogs with idiopathic male feminizing syndrome, however, four dogs in our study did not have gynecomastia.

Hypoandrogenism diagnosis of based on signalment, history, and physical examinations; the results of routine biochemistry and hormone tests, skin scrapings and the response to treatment (Cerendolo, 2009; Feldman and Nelson, 1996). The normal values of blood testosterone in male dogs is $500-6000 \mathrm{ng} / \mathrm{dl}$ according to our laboratory. Dogs below these values are considered hypoadrenogenic (Table 1).

Hypoandrenogenism has been reported as occurring most frequently in the Siberian husky, Alaskan Malamute, Keeshond, and Chow Chows (Scott and Paradis, 1990). Although Golden Retrievers were the 
most common breed in our study, the Siberian Husky was the second. We hypothesize that this breed differs according to the breed populations in our country.

Genital skin is more sensitive to androgenic hormones. Androgens increase the epidermal thickness (Schmeitzel, 1990). The majority of cases have symmetrical alopecia and hyperpigmentation, and seborrhea in previously reported cases of hypoandrogenism (Mulligan, 1944; Schmeitzel, 1990; Scott et al., 2001). In the present study, all dogs had the same clinical symptoms. Alopecia initially begins in the perineal, genital, and ventral abdominal regions and then spreads cranially (Feldman and Nelson, 1996). Only one in four dog lesions started from the neck in our study. All seventy-six dogs were referred from other clinics due to chronic dermatosis so maybe this variation is due to the treatments.

All dogs in this study were treated with testosterone and after the treatment; a resolution of the symptoms was seen within a month. However, follow-up information was not available in all cases after a month.

Keratinocytes, melanocytes, collagen fibers, and dermal ground substance can be affected by sex hormones. However, little is known about the mechanism of this condition (Bratha-Robia et al., 2002; Schmeitzel, 1990). It is thought to relate to the effect of hormones on the hair follicle, and the inhibition of the normal cyclic pattern of the hair growth (Frank et al., 2003). Androgens progressively reduce the anagen phase of the hair cycle in humans until a hair shaft is no longer produced (Crabtree et al., 2010). At the same time, androgens increase cutaneous pigmentation in certain species and the size of the sebaceous gland and sebum production in many species (Mulligan, 1944; Schmeitzel, 1990). Also, thinning of the epithelium of the hair follicles was seen (Mulligan, 1944).

In a study by Bratha-Robia et al. (2002) specific localization of the estrogen receptors (ER) and androgen receptors (AR) were searched for in the canine skin and hair follicles by immunohistochemistry. Interestingly, the number of AR-positive cells found was significantly higher in the samples from the thorax and the flank (Bratha-Robia et al., 2002).
In summary, this study indicates that although hypoandrogenism is thought to be one of the rarest causes of symmetrical alopecia in male dogs maybe it is not that uncommon. In reviewing the information from this study, hypoadrenogenism should be included in the differential diagnosis of symmetrical alopecia in male dogs with clinical manifestation of symmetrical alopecia.

\section{Acknowledgement}

The author would like to thank Vetlab laborotories in Turkey for providing access to their records for this study.

\section{References}

Bratha-Robia, C.B., Egerbacher, M., Helmreich, M., Mitteregger, G., Benesch, M., Bamberg, E. (2002). Immunohistochemical localization of androgen and oestrogen receptors in canine hair follicules. Vet Dermatol, 13, 113-118.

Cerundolo, R. (2009). Sex hormone alopecia in dogs. Comp. Anim. 14(8):1-5.

Crabtree, J.S., Kilbourne, E.J., Peano, B.J., Chippari, S., Kenney, T., McNally, C., Wang, W., Harris, H.A., Winneker, R.C., Nagpal, S., Thompson, C.C. (2010). A Mouse model of androgenetic alopecia. Endocrinology, 15(5), 2373-2380.

Feldman, E.C., Nelson, R.W. (1996). Canine and Feline Endocrinology and reproduction. W. B. Saunders, Philadelphia. p. 64

Frank, L.A., Hnılıca, K.A., Rohrbach, B.W., Oliver, J.W. (2003). Retrospective evaluation of sex hormones and steroid hormone intermediates in dogs with alopecia. Vet Dermatol, 14, 91-97.

Ginel, P.J., Lucina, R., Millan, Y., Gonzales-Medina, S., Guil, S., Garcia-Monterde, J., Espinosa de los Monteros, A., Martın de los Mulas, J. (2009). Expression of oestrogen and progesterone reseptors in canine sebaceous glandtumours. Vet Dermatol, 21, 297 302.

Gündüz, A.Ü., Gündüz, M.C., Bilgiç, İ., Arun, S. (2002). Dermatosis in a german shepherd with hyperestrogenism, hypoandrogenizm and hypersensitivity. KHVHD, 19-22.

Mulligan, R.M. (1944). Feminization in male dogs a syndrome associated with carcinoma of the testis and mimicked by the administration of estrogens. Amer Journ of Pathol, 20(5), 865-875.

Rosychuck, R.A.W. (2008). Cutaneous manifestations of endocrine disease in Dogs. The Compendium, 20(3), 287302. 
Schmeitzel, L.P. (1990). Sex hormone-related and growth hormone-related alopecias. Vet Clin of North America: Small Anim Pract, 20(6), 1579-1601.

Scott, D.W., Miller, W.H., Griffin, C.E. (2001). Endocrine and metabolic diseases. In: Muller \& Kirk's small animall animal dermatology 6th edn. W. B. Saunders, Philadelphia. p 796-797

Scott, D.W., Paradis, M.A. (1990). Survey of canine and feline skin disorders seen in a university practise: Small animal clinic, university of Montreal, Saint-Hyacinthe, Quebec (1987-1988). Can Vet Journal, 31, 30-835. 